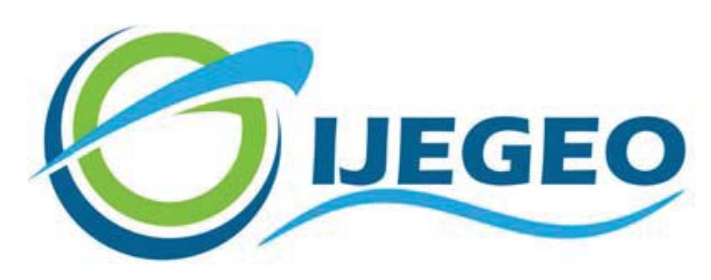

International Journal of Environment and Geoinformatics (IJEGEO) is an international, multidisciplinary, peer reviewed, open access journal.

\title{
Highway route planning via least cost path algorithm and multi criteria decision analysis integration, a comparison of AHP, TOPSIS and VIKOR
}

\section{Fatih SARI, Mehmet ŞEN}

\author{
Chief in Editor \\ Prof. Dr. Cem Gazioğlu \\ Co-Editors Prof. Dr. Dursun Zafer Şeker, Prof. Dr. Şinasi Kaya, \\ Prof. Dr. Ayşegül Tanık and Assist. Prof. Dr. Volkan Demir
}

Editorial Committee (June 2022)

Assoc. Prof. Dr. Abdullah Aksu (TR), Assoc. Prof. Dr. Uğur Algancı (TR), Assoc. Prof. Dr. Aslı Aslan (US), Prof. Dr. Levent Bat (TR), Prof. Dr. Paul Bates (UK), İrşad Bayırhan (TR), Prof. Dr. Bülent

Bayram (TR), Prof. Dr. Luis M. Botana (ES), Prof. Dr. Nuray Çağlar (TR), Prof. Dr. Sukanta Dash (IN), Dr. Soofia T. Elias (UK), Prof. Dr. A. Evren Erginal (TR), Assoc. Prof. Dr. Cüneyt Erenoğlu (TR), Dr. Dieter Fritsch (DE), Prof. Dr. Ç; Prof. Dr. Manik Kalubarme (IN), Dr. Hakan Kaya (TR), Assist. Prof. Dr. Serkan Kükrer (TR), Assoc. Prof. Dr. Maged Marghany (MY); Prof. Dr. Micheal Meadows (ZA), Prof. Dr. Nebiye Musaoğlu (TR), Prof. Dr. Masafumi Nakagawa (JP), Prof. Dr. Hasan Özdemir (TR), Prof. Dr. Chyssy Potsiou (GR), Prof. Dr. Erol Sarı (TR), Prof. Dr. Maria Paradiso (IT), Prof. Dr. Petros Patias (GR), Prof. Dr. Elif Sertel (TR), Prof. Dr. Nüket Sivri (TR), Prof. Dr. Füsun Balık Şanlı (TR), Dr. Duygu Ülker (TR), Prof. Dr. Seyfettin Tsaş (TR), Assoc. Prof. Dr. Ömer Suat Taşkın (TR), Assist. Prof. Dr. Tuba Ünsal (TR), Assist. Prof. Dr. Sibel Zeki (TR) 


\title{
Highway route planning via least cost path algorithm and multi criteria decision analysis integration, a comparison of AHP, TOPSIS and VIKOR
}

\author{
Fatih Sarı"* iD, Mehmet $\operatorname{Şen}^{2}$ iD \\ ${ }^{1}$ Konya Technical University, Faculty of Engineering and Natural Sciences, Geomatic Engineering Department, Konya, Turkey \\ ${ }^{2}$ Turkey, General Directorate of Land Registry and Cadastre Konya/Turkey
}

* Corresponding author: F. Sarı

Received 20.03.2021

E-mail: fsari@ktun.edu.tr

Accepted 02.10.2021

How to cite: Sarı and Şen (2022). Highway route planning via least cost path algorithm and multi criteria decision analysis integration, a comparison of AHP, TOPSIS and VIKOR, International Journal of Environment and Geoinformatics (IJEGEO), X(Y): 000-000. doi. 10.30897/ijegeo. 900200

\begin{abstract}
Highways are one of the main structures of cities in the field of economic, social, and environmental facilities that connect cities, regions, and people each other. Determining the suitable highway routes includes difficult and complex processes due to the construction costs. Additionally, priorities, expectations, and constraints for economic, social, and environmental parameters must be considered together to provide efficient solutions to requirements. Multi Criteria Decision Analysis (MCDA) techniques such as Analytical Hierarchy Process (AHP), Ideal Solution Similarity Selection Ranking Technique (TOPSIS), and Vise Kriterijumska Optimizacija I Kompromisno Resenje (VIKOR) and Least Cost Path Algorithm (LCPA) with Geographical Information Systems (GIS) combination are the most suitable way to overcome these complexities. In this study, slope, aspect, geology, elevation, distances to roads, settlements, water bodies, fault lines, buildings, natural disasters, protected sites, population, and land use were selected to determine most suitable highway construction areas and route. The AHP, TOPSIS, and VIKOR methods were applied to calculate cost surfaces for least cost paths generation with LCPA, and the generated three routes were compared. As a result of the comparisons VIKOR route was the most suitable route considering the topographical statistics and all the three methods consistent with each other and current road.
\end{abstract}

Keywords: Multi-Criteria Decision Analysis, Analytical Hierarchy Process, Least Cost Path Algorithm, Geographical Information Systems

\section{Introduction}

The transportation systems have an importance that can accelerate the development of a country with its economic contributes. There is a very close relation between the transportation system of a city and its economic and social status (Vaghela et al., 2018; Mohammadi and Hosseinal1, 2019Tanga and Waters, 2005). Thus, the analysis and planning of highways in developing cities are very important in the field of economic, social, and environmental parameters (Black, 2003). The highway planning has some conflicts between economic and environmental perspective. Considering the cost parameter can have negative effects on the environment and habitat due to the demonstrated forests, changed water resources directions, construction wastes, air pollution, and noise. On the other hand, environmental oriented highway projects can increase the cost due to the higher slope, elevation values, and additional constructions like tunnels, bridges, and culverts. There are large amounts of study, which initialize the effects of highways to the environments. The issue of road planning has received considerable critical attention. The effects of highways on the habitat have been studied by Jung et al. (2013) and Morelli et al. (2014). The contributors of highways to deforestation have been studied by Freitas et al. (2010), Holderegger and Giulio(2010), Lewis et al. (2011), Abbott et al. (2012), Barber et al. (2014), and Newman et al. (2014). Environmental effects of the roads have been examined by Coffin (2007) and Schweikert et al. (2014). The effects of the highways on the agricultural lands have been studied by Saunders et al. (2002), Funderburg et al. (2010), Datta (2012), Wu et al. (2014), and Zhang et al. (2015). Some of the studies about traffic related pollutants and air quality have been conducted by Pattinson et al. (2014), Patton et al. (2014), Batterman et al.(2015), Yazdi et al., (2015) , and Castaneda et al. (2016). Due to the negative effects of highway projects on the environment, considerably, the cost of the projects is getting increased. The environmental and cost priorities of the highway projects must be considered when examining the most suitable highway routes.

A considerable amount of literature has been published on road planning (Burak et al., 2004; Çepni and Arslan, 2017). One of main obstacles in road planning is that multi-factor must be considered. However, the synthesis of these factors remains a major challenge. The environmental or cost oriented highway projects can be defined with AHP which is the most applied method in MCDA and is based on an application used to determine the best solutions to the real problems. AHP has a high rate of application in a wide variety of disciplines with 
spatial and non-spatial data compared to others such as the TOPSIS, and VIKOR (Hwang and Yoon, 1981; Arentze and Timmermans, 2000). TOPSIS is based on a distance calculation which assigns the shortest distances from positive ideal solution as the best alternative (Hwang and Yoon, 1981). The VIKOR method is based on a ranking measurement which is determined by calculating the closeness of the alternatives (Opricovic, 1998).

LCPA algorithm is used to determine the route alternatives of highways with MCDA integration. LCPA provides users to find the cheapest route that connects two locations using a cost surface determined by considering multiple criteria (Hassan and Effat, 2013). The cost surface can be produced via GIS and the cost criteria can be evaluated and weighted with AHP. Some of the studies on LCPA involve selecting the fastest path with the least slope (Stefanakis and Kavouras, 1995), selecting three alternatives between destination and origin points (Hassan and Effat, 2013), and determining arctic all weather road (Atkinson et al., 2005), optimal route from multiple destination and origin points (Lee and Stucky, 1998) and multi-criteria based cost surfaces (Douglas, 1994; Collischonn and Pilar, 2000).

Although there is a growing body of literature that recognizes multi-perspective approach in road planning, to date, there are few studies that have assessed multi factor for road design. This study shows the suitable highway locations and routes that determined by GIS based AHP and LCPA integration for operational solutions. While AHP determines the most suitable locations, LCPA decides the route considering the weights of parameters that calculated with AHP. GIS and AHP integration provides a cost surface to the LCPA such as environmental, economic, and social factors thus, the routes could be determined according to the desired parameter oriented approach. In this study, it was aimed to determine the most suitable highway locations by the TOPSIS, AHP, and VIKOR methods. Moreover, three alternative routes were generated by AHP, TOPSIS and VIKOR cost surfaces were compared with current routes to define the methods consistency.

\section{Materials and Methods Study Area}

Konya city is located in the middle of Turkey and has 31 districts. It has the largest area in Turkey and the area of the entire Konya is $40814 \mathrm{~km} 2$ (Figure 1). The population of the city is 2.108 .808 according to the 2014 Census (Turkish Statistical Institute, 2019). A large amount of the population is settled in the city center, and the city has a rapidly increasing population trend with $6 \%$.

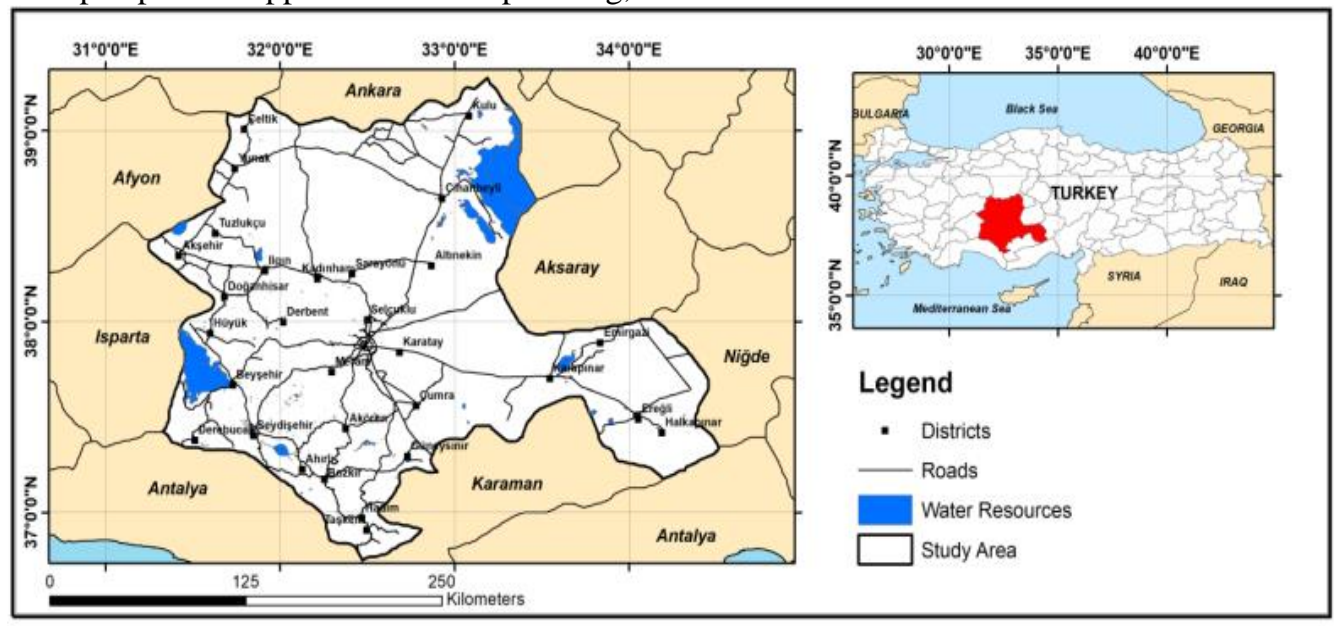

Fig. 1. Study Area (Konya City)

Konya has the largest highway network with the 3.045 kilometer length in Turkey. Due to the geographical position, it is a crossroad for transportation between south and north. A large number of logistic vehicles use Konya highways on a daily basis to transport domestic and international livestock, agricultural and industrial products.

\section{Decision and Evaluation of Criteria}

Decision problems are depend on a set of criteria, include attributes and objectives, and should have features to adequately represent multiple criteria (Malczewski and Rinner, 2015)

The set of evaluation criteria can be defined by the interested literature, analytical study, and opinions (Malczevski, 1999). As a result of the literature reviews and expert opinions, 14 criteria were considered within geological, environmental, economic, social, and topographic aspects. The defined criteria and their explanations were given below;

Slope (SL): Slope is the basic elements of the highway constructions with its cost increasing effect. Steep slopes lead to higher excavation costs. Slope map was generated using 30 meter spatial resolution ASTER GDEM data.

Aspect (AS): Aspect is land surface direction, also known as slope direction wherein values indicate the compass direction of surface faces at that location. Aspect criterion is considered to be able to determine directions and their effects on roads. Aspect data were derived from ASTER GDEM elevation model at 30x30 meter resolution. 
Elevation (EL): The importance of the elevation must be considered together with climate conditions of the region. The elevation varies from 770 to 3419 in Konya and has hard climatic conditions above 1500 meters. Especially at the elevation above 1800 meters, the region has really hard winter conditions with snow, very low temperature, and fog. Elevation maps retrieved from ASTER GDEM database.

Geology (GL): Lithological features of the area have a very close relationship with the cost factor of highway constructions. While solid surfaces like rocky lands increase the excavation cost, the stability of the highway is provided mostly by rocks. The swamp areas are not suitable for constructions because these areas tend to corruption and distortion. Geological data were retrieved from General Directorate of Mineral Research and Exploration Institute.

Distance to Faults (DtF): Fault lines usually cause collapse and segmentation on the land surface. These have negative effects on road suitability and construction. Fault lines were retrieved from General Directorate of Mineral Research and Exploration Institute.

Distance to Water Resources (DtW): Rivers, dams, and lakes are considered to avoid construction costs of vents and bridges. Water resources data were retrieved from Open Street Map database.

Distance to Water Wells (DtWe): Konya has over 100.000 water wells due to the intensive agricultural activities. Water wells are one of the main factors of collapse on the road surfaces. The data were retrieved from General Directorate of State Hydraulic Works Institute.

Land Use (LU): For the reason that highway constructions have a close relationship with land formation, land use/cover must be considered. The area is divided into six groups as urban area, water resources, forest, mountains, agriculture, and bare lands. Although highway construction is substantially important for developing industry and urbanization, protecting environmental facilities must be considered when planning highway routes. Land use map was generated from CORINE 2018 Map.

Natural Disasters (ND): Similar to fault lines, natural disaster areas such as landslide, flood basins, and sinkholes have vital importance on road stability. Disaster data were retrieved from Disaster and Emergency Management Presidency of Turkey.

Protected Sites (PS): Protected site data includes habitat, endemic, and archaeological sites which must be protected from human made objects and their negative effects. The data were retrieved from Disaster and Emergency Management Presidency of Turkey.

Distance to Settlements (DtS): Settlements were considered to provide the use of rest areas, fill stations, and other facilities. Distances to settlements were classified from 1000 to 9000 meters. The settlements data were retrieved from Open Street Map database.

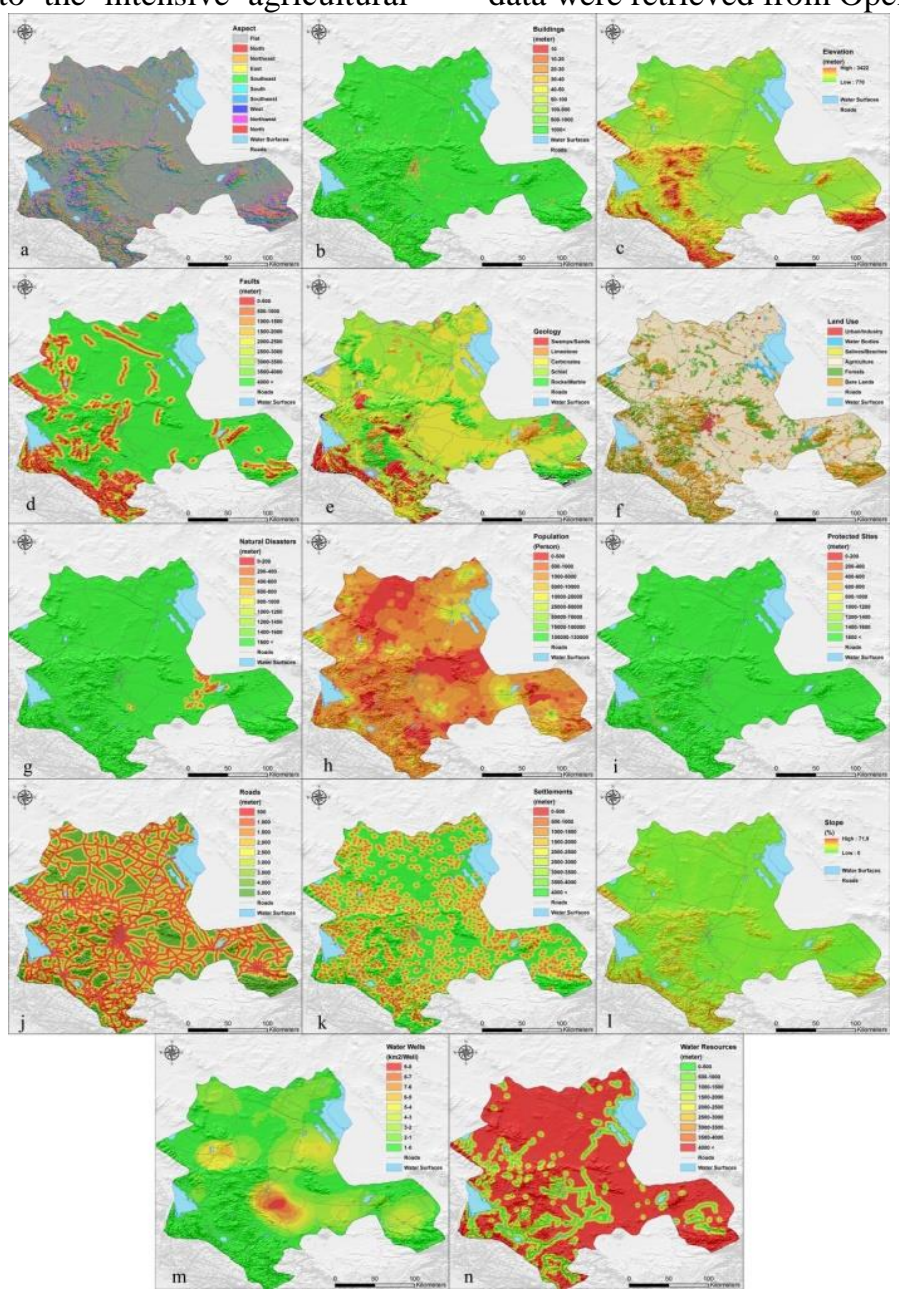

Fig. 2. a) Aspect, b) Buildings, c) Elevation, d) Fault lines, e) Geology, f) Land use, g) Natural Disasters, h) Population, i) Protected Sites, j) Roads, k) Settlements, l) Slope, m) Water Wells, n) Water Resources. 
Population (PO): Populations of the settlements were considered to locate new highways according to the population density. Population values were retrieved from Turkish Statistical Institute web site (Turkish Statistical Institute, 2019) for last census 2016 for 584 settlements.

Buildings (BU): Buildings criterion was considered to prevent road route and building intersection. The buildings data were retrieved from Open Street Map database and

Distance to Roads (DtR): Distances from the highways were considered to determine which locations needed new highway. Distances from the highways were classified from 1000 to 9000 meters, and ones higher than 9000 meters should have a higher weight to determine the regions far from existing highways. Highway map was retrieved from Open Street Map database.

Each criterion map was generated considering the defined classes in GIS environment, and all the maps are given in Figure 2.

\section{Analytical Hierarchy Process (AHP)}

The AHP method proposed by Saaty $(1977 ; 1980)$ calculates the importance of each criterion, from 1 to 9 relatively (1=Equal, 3=Moderately, 5=Strongly, 7=Very, $9=$ Extremely). The pairwise comparison matrix includes the scales $\left(\mathrm{a}_{\mathrm{nn}}\right)$ which is used to determine the importance of each criterion.

\begin{tabular}{c|ccccc} 
A & Criteria 1 & Criteria 2 & Criteria 3 & $\ldots$ & Criteria n \\
\hline Criteria 1 & $a_{11}$ & $a_{12}$ & $a_{13}$ & $\ldots$ & $a_{1 n}$ \\
Criteria 2 & $a_{21}$ & $a_{22}$ & $a_{23}$ & $\ldots$ & $a_{2 n}$ \\
$\ldots$ & $\ldots$ & $\ldots$ & $\ldots$ & $\ldots$ & $\ldots$ \\
Criteria $\boldsymbol{n}$ & $a_{n 1}$ & $a_{n 2}$ & $a_{n 3}$ & $\ldots$ & $a_{n n}$
\end{tabular}

A normalized matrix is generated by a division of each element to the sum of its own column sum with Formula 2.

$a_{i j}^{1}=\frac{a_{i j}}{\sum_{i=1}^{n} a_{i j}}$

The average of the sum refers to the weights of each criterion (Formula 3 ).

$w_{i}=\left(\frac{1}{n}\right) \sum_{i=1}^{n} a_{i j}^{\prime},(i, j=1,2,3, \ldots, n)$

Saaty (1994) has proposed a Consistency Index (CI) calculation to decide whether the comparisons are consistent or not. $C I$ is an indicator of the consistency of pairwise comparison matrix (Formula 4).

$C I=\frac{\lambda_{\max }-n}{n-1}$

$C I$ calculation requires to determine $\lambda_{\max }$ (eigen value) value with Formula 5 and Random Index (RI) value according to the matrix order (1,57, in this study).

$\lambda_{\max }=\frac{1}{n} \sum_{i=1}^{n}\left[\frac{\sum_{j=1}^{n} a_{i j} w_{j}}{w_{i}}\right]$

Consistency Ratio ( $C R$ ) refers to the total consistency of AHP calculation (Formula 6). If $C R$ is greater than 0.1, importance of each criterion must be reconsidered (Saaty, 1980).

$C R=\frac{C I}{R I}$

\section{TOPSIS}

In evaluation matrix $A_{i}, A=(1,2, \ldots, n)$ represents the alternatives and $C_{i}, C=(1,2, \ldots, m)$ a set of criteria where $X_{i}\left(X_{11}\right.$ to $\left.X_{n m}\right)$ defines the ratings.

\begin{tabular}{c|ccccc} 
& $\boldsymbol{C}_{\boldsymbol{I}}$ & $\boldsymbol{C}_{\boldsymbol{2}}$ & $\boldsymbol{C}_{\boldsymbol{3}}$ & & $\boldsymbol{C}_{\boldsymbol{m}}$ \\
\hline $\boldsymbol{A}_{\boldsymbol{I}}$ & $X_{11}$ & $X_{12}$ & $X_{13}$ & $\cdots$ & $X_{1 m}$ \\
$\boldsymbol{A}_{\mathbf{2}}$ & $X_{21}$ & $X_{22}$ & $X_{23}$ & $\cdots$ & $X_{2 m}$ \\
$\cdots$ & $\cdots$ & $\ldots$ & $\cdots$ & $\cdots$ & $\cdots$ \\
$\boldsymbol{A}_{\boldsymbol{n}}$ & $X_{n 1}$ & $X_{n 2}$ & $X_{n 3}$ & $\cdots$ & $X_{n m}$
\end{tabular}

$R$ and $V$ matrices represent normalized weighted decision matrices considering the ratings with Formula 8 and 9 (Hwang and Yoon, 1981).

$r_{i j}(x)=\frac{x_{i j}}{\sqrt{\sum_{i=1}^{n} x_{i j}^{2}}}, \quad i=1, \ldots, n, j=1, \ldots, m$
$v_{i j}(x)=w_{i} x r_{i j}(x), \quad i=1, \ldots, n, j=1, \ldots, m$

While positive ideal solution consists of the largest element of the weighted normalized decision matrix $V$, negative ideal solution consists of the smallest element (Formula 10).

$$
\begin{aligned}
& \mathrm{A}^{+}=\left\{\mathrm{V}_{1}^{+}(\mathrm{x}), \mathrm{V}_{2}^{+}(\mathrm{x}), ., \mathrm{V}_{\mathrm{m}}^{+}(\mathrm{x})\right\} \\
& =\left\{\left(\max _{i} v_{i j}(x) \mid j \in j_{1}\right) \min _{i} v_{i j}(x) \mid j\right. \\
& \left.\in j_{2} \mid i=1, n\right\} \\
& \mathrm{A}^{-}=\left\{\mathrm{V}_{1}^{-}(\mathrm{x}), \mathrm{V}_{2}^{-}(\mathrm{x}), ., \mathrm{V}_{\mathrm{m}}^{-}(\mathrm{x})\right\} \\
& =\left\{\left(\min _{i} v_{i j}(x) \mid j \in j_{1}\right) \max _{i} v_{i j}(x) \mid j\right. \\
& \left.\in j_{2} \mid i=1, n\right\}
\end{aligned}
$$

$D i^{*}$ and $D_{i}{ }^{-}$calculations include an Euclidean distance determination that separates the alternatives from the positive and negative ideal solutions. The number of $D i^{*}$ and $D_{i}{ }^{-}$should be equal to the number of alternatives (Peters and Zelewski, 2007; Triantaphyllou, 2000).

$D_{i}^{*}=\sqrt{\sum_{j=1}^{m}\left\lfloor V_{i j}(X)-V_{j}^{+}(X)\right\rfloor^{2}}, \quad D_{i}^{-}=$

$\sqrt{\sum_{j=1}^{m}\left\lfloor V_{i j}(X)-V_{j}^{-}(X)\right]^{2}}, i=1, \ldots, n$

As a result, relative closeness to the ideal solution $C_{i}^{*}$ (1 $>C_{i}^{*}>0$ ) decides better solution with closeness to 1 (Formula 12).

$C_{i}^{*}=\frac{D_{k}^{-}}{D_{k}^{*}+D_{k}^{-}}, \quad C_{i}^{*} \in[0,1], \forall i=1, \ldots, n$

\section{VIKOR}

The VIKOR method starts with the following Formula 13 ,

$\mathrm{L}_{\mathrm{p}, \mathrm{j}}=\left\{\sum_{i=1}^{n}\left[\frac{w_{i\left(f_{i}^{*}-f_{i j}\right)}}{f_{i}^{*}-f_{i}^{-}}\right]^{P}\right\}^{1 / P} 1 \leq P \leq \infty, \quad j=$ 
Within the VIKOR method, a ranking measure is established with $L_{1, j}=S_{j}$ and $L_{\infty j}=R_{j}$. The minimum $S_{j}$ solution represents the maximum group utility, and the minimum solution $R_{j}$ represents the individual regret of the opponent (Yu, 1973; Zeleny, 1982; Opricovic, 1998). Best $f_{i}^{*}$ and the worst $f_{i}^{-}$values, $(i=1,2, . ., n)$,

$f_{i}^{*}=\max _{j} f_{i j}, f_{i}^{-}=\min _{j} f_{i j}, \quad$ represents a benefit $f_{i}^{*}=\min _{j} f_{i j}, f_{i}^{-}=\max _{j} f_{i j} \quad$ represents a cost

will be used to calculate the values $S_{j}$ and $R_{j}$ with Formula 15,

$S_{j}=\frac{\sum_{i=1}^{n} w_{i}\left(f_{i}^{*}-f_{i j}\right)}{\left(f_{i}^{*}-f_{i j}\right)}, R_{j}=\max _{i}\left[\frac{w_{i}\left(f_{i}^{*}-f_{i j}\right)}{\left(f_{i}^{*}-f_{i j}\right)}\right], \mathrm{j}=$
$1,2, \ldots, \mathrm{J}$

where $w_{i}$ are the weights of criteria.

Compute the values $Q_{j} ; j=1,2, \ldots, m$, by the Formula 16

$Q_{j}=\frac{v\left(S_{j}-S^{*}\right)}{\left(S^{-}-S^{*}\right)}+\frac{(1-v)\left(R_{j}-R^{*}\right)}{\left(R^{-}-R^{*}\right)}$

where $S^{*}=\min _{j} S_{j}, S^{-}=\max _{j} S_{j}, R^{*}=$ $\min _{j} R_{j}, R^{-}=\max _{j} R_{j}$

The best ranked $Q$ (minimum) measure is proposed as the best solution.

\section{Generating Routes - Least Cost Path Algorithm}

Most of the routing methods involve least-cost algorithms and Dijkstra's and the Bellman-Ford algorithms are the most widely used algorithms (Nader,
2006). Dijkstra's algorithm is based on a distance calculation from origin to destination that aims generating least cost path. Dijkstra's algorithm is as follows: (Rees, 2004),

1. Zero value is assigned to the target cell.

2. All the neighboring cells are included in an active cell list. In this step, costs to the target cell are calculated.

3. The pixel which has the lowest cost is named as C, and its cost is named as $\mathrm{k}$;

4. All the neighboring cells of $\mathrm{C}$ are named as $\mathrm{S}$. A cost 1 calculation for each cell is determined when moving to C.

4.1. If $\mathrm{C}$ is not involved in the list, $\mathrm{C}$ is added with a $\mathrm{k}+$ 1 cost value,

4.2. If $\mathrm{C}$ is included in the list, a comparison is realized for the pixel value and cost value. If cost value is less than pixel value, assign $\mathrm{k}+1$ value for $\mathrm{C}$.

5. The smallest distance is selected and the processes are repeated from the 3rd order until all the values are calculated (Rees, 2004), (Dijkstra, 1959).

\section{Results}

Each criterion classes were specified considering the suitability values and assigned preference values from 1 to 9. A Pairwise comparison matrix includes all criteria and their related preference values to be able to calculate the weights. The consistency ratio of the AHP calculation was 0.045 which means preference values were consistent. Pairwise matrix and calculated weights are given in Table 1.

Table 1. AHP Pairwise comparison matrix and preference values

\begin{tabular}{|c|c|c|c|c|c|c|c|c|c|c|c|c|c|c|c|}
\hline Criteria & SL & GL & DtW & DtF & $\mathbf{L U}$ & ND & DtWe & PS & $\mathbf{A S}$ & EL & DtS & PO & BU & DtR & Weight \\
\hline SL & 1 & 0,4 & 3,5 & 3,1 & 0,4 & 2,5 & 5 & 2 & 3 & 0,4 & 5 & 3 & 2,5 & 5 & 0,093 \\
\hline GL & & 1 & 4 & 4 & 0,5 & 3 & 6 & 2,2 & 4 & 0,5 & 6 & 4 & 3 & 6 & 0,125 \\
\hline DtW & & & 1 & 1 & 0,1 & 1,6 & 3,5 & 0,7 & 1,1 & 0,1 & 3,5 & 1,8 & 1,1 & 1,7 & 0,041 \\
\hline DtF & & & & 1 & 0,1 & 0,9 & 1,3 & 0,7 & 1 & 0,1 & 1,2 & 1 & 0,8 & 1,2 & 0,029 \\
\hline $\mathbf{L U}$ & & & & & 1 & 6 & 9 & 4,5 & 7,8 & 0,9 & 9 & 7,8 & 6,5 & 9 & 0,228 \\
\hline ND & & & & & & 1 & 0,5 & 0,5 & 0,7 & 0,9 & 2 & 1 & 0,7 & 1 & $\mathbf{0 , 0 4 0}$ \\
\hline DtWe & & & & & & & 1 & 0,25 & 0,3 & 0,35 & 1 & 0,5 & 0,3 & 0,6 & 0,025 \\
\hline PS & & & & & & & & 1 & 1,4 & 0,2 & 2,5 & 1,5 & 1,1 & 2,5 & 0,052 \\
\hline $\mathbf{A S}$ & & & & & & & & & 1 & 0,1 & 1,5 & 1 & 0,9 & 1,5 & 0,035 \\
\hline EL & & & & & & & & & & 1 & 9 & 8,5 & 7,2 & 9 & 0,218 \\
\hline DtS & & & & & & & & & & & 1 & 0,7 & 0,5 & 1 & $\mathbf{0 , 0 2 0}$ \\
\hline PO & & & & & & & & & & & & 1 & 0,9 & 1,5 & 0,031 \\
\hline BU & & & & & & & & & & & & & 1 & 2 & 0,041 \\
\hline DtR & & & & & & & & & & & & & & 1 & $\mathbf{0 , 0 2 3}$ \\
\hline
\end{tabular}

Table 2. Evaluation matrix for TOPSIS and VIKOR

\begin{tabular}{ccccccccccccccc}
\hline Criteria & SL & GL & DtW & DtF & LU & ND & DtWe & PS & AS & EL & DtS & PO & BU & DtR \\
\hline Weights & 0,09 & 0,12 & 0,04 & 0,03 & 0,24 & 0,04 & 0,03 & 0,05 & 0,03 & 0,23 & 0,02 & 0,03 & 0,04 & 0,02 \\
\hline LU1 & 8 & 9 & 9 & 9 & 6 & 9 & 9 & 9 & 3 & 5 & 5 & 4 & 9 & 4 \\
LU2 & 7 & 9 & 9 & 9 & 6 & 9 & 9 & 9 & 9 & 5 & 7 & 4 & 9 & 3 \\
LU3 & 6 & 9 & 9 & 9 & 6 & 9 & 9 & 9 & 3 & 5 & 4 & 2 & 9 & 9 \\
$\ldots$ & $\ldots$ & $\ldots$ & $\ldots$ & $\ldots$ & $\ldots$ & $\ldots$ & $\ldots$ & $\ldots$ & & & & & & \\
LU1498 & 5 & 5 & 9 & 9 & 6 & 9 & 9 & 9 & 9 & 5 & 1 & 2 & 9 & 1 \\
LU1499 & 8 & 1 & 9 & 9 & 2 & 9 & 9 & 9 & 9 & 4 & 5 & 2 & 9 & 2 \\
LU1500 & 8 & 9 & 8 & 9 & 6 & 9 & 9 & 9 & 7 & 5 & 8 & 3 & 9 & 7 \\
\hline
\end{tabular}

For the purpose of constituting an evaluation matrix, there are 1500 test points specified in the study area (Figure 3). The test points were specified by identifying a homogeneous distribution to the study area and they are related ranking values for 14 criteria. Each value for test points were assigned by extracting raster values to points. The ranking values for each criterion are assigned to each test point between 1-9 considering the highway requirements (Table 2 ). 


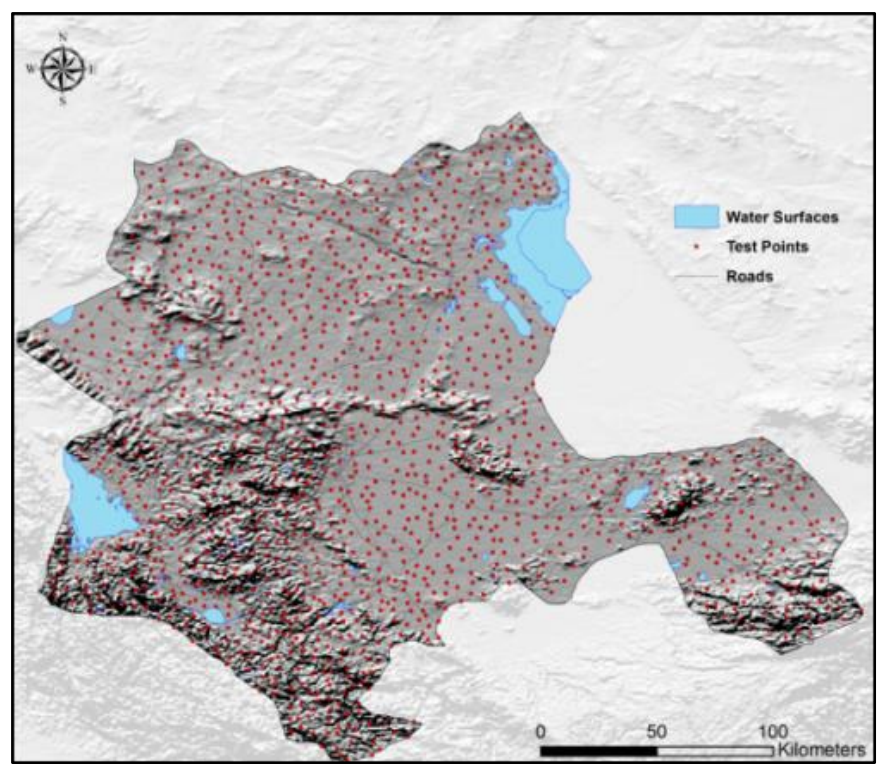

Figure 3. The distribution of the test points in the study area.

Table 3.TOPSIS and VIKOR ranking values

\begin{tabular}{lcccccc}
\hline & & TOPSIS & & & \multicolumn{2}{c}{ VIKOR } \\
\hline LU & $\mathbf{D}_{\mathbf{i}}{ }^{*}$ & $\mathbf{D}_{\mathbf{i}}{ }^{-}$ & $\mathbf{C}_{\mathbf{i}}{ }^{*}$ & $\mathbf{S}$ & $\mathbf{R}$ & $\mathbf{Q}$ \\
\hline LU1 & 0,0029 & 0,0093 & 0,7596 & 0,1542 & 0,080 & 0,2201 \\
LU2 & 0,0029 & 0,0093 & 0,7610 & 0,1435 & 0,080 & 0,2128 \\
LU3 & 0,0033 & 0,0092 & 0,7368 & 0,1828 & 0,080 & 0,2396 \\
$\ldots$ & $\ldots$ & $\ldots$ & $\ldots$ & $\ldots$ & $\ldots$ & $\ldots$ \\
LU1498 & 0,0038 & 0,0086 & 0,6903 & 0,2621 & 0,08 & 0,2936 \\
LU1499 & 0,0073 & 0,0050 & 0,4185 & 0,4907 & 0,184 & 0,6857 \\
LU1500 & 0,0029 & 0,0094 & 0,7635 & 0,1330 & 0,080 & 0,2057 \\
\hline
\end{tabular}

After the weights and evaluation matrix calculation, TOPSIS technique is used to determine the test point rankings. The TOPSIS technique is based on a calculation that the best alternative should have the shortest distance from positive ideal solution. The ranking values are used to determine $R$ and $V$ matrices via $W$ criterion weights that calculated with AHP. The positive ideal solution $A^{+}$and the negative ideal solution $A^{-}$, which are the maximum and minimum values of the $V$ matrix, are calculated. Based on the $A^{+}$and $A^{-}$values, distance to positive ideal solutions $D i^{*}$ and distance to negative ideal solution $D_{i}^{-}$values are calculated for each test point. Finally, relative closeness to ideal solution $\mathrm{Ci}^{*}$ values is calculated (Table 3 ) to determine the highway suitability ranking definition.

In addition to the TOPSIS method, VIKOR method requires to specify the best $f i^{+}$and $f i$ values. Determining the suitability of each test point depends on ranking alternatives by sorting $\mathrm{Q}$ values from low to high which refers to a suitability order. The minimum $Q$ value demonstrates the highest suitability and the maximum $Q$ value demonstrates lowest suitability. However, stability of the decision must be evaluated. Proposing $Q$ value as a compromise solution, condition 1 and condition 2 are evaluated. For acceptable advantage (C1), $Q\left(a^{\prime \prime}\right)-Q\left(a^{\prime}\right) \geq 1 /(1-1500)$ equation is not satisfied for this calculation. Thus, the condition 2 is satisfied for $\mathrm{v}=0.5$ value by consensus. Suitability calculations for TOPSIS and VIKOR according to the $\mathrm{Ci}^{*}$ and $Q$ values are given in Table 3 .

LCPA calculation requires a cost attribute to assign a value when moving from origin to destination cell. The cost parameter can be a single criterion (such as elevation, slope) or a combination of multiple criteria. In this study, generated AHP, TOPSIS, and VIKOR suitability maps were used as cost surfaces in LCPA. The weights determined with AHP (Table 1) were used to generate the AHP cost surfaces and calculated with the following equation;

AHP Cost Surface $=\sum_{i=1}^{n}=$ wi.ri $=W_{A S} . \mathrm{AS} \quad+$ $W_{G L .} G L+W_{D t W .} D t W+W_{D t S} . D t S+$ $W_{D t F .} D t F+W_{E L .} E L+W_{L U .} L U+W_{N D .} N D+$ $W_{D t W e .} D t S W e+W_{P S} P S+W_{A S} A S+W_{P O} P O+$ $W_{B U .} B U+W_{D t R .} D t R$

TOPSIS and VIKOR cost surfaces are generated via Inverse Distance Weighted (IDW) method considering $C_{i}^{*}$ and $Q$ values. The cost surface values tend to be between minimum 1 and maximum 9 Saaty, (1977).

\section{Creating Suitability Maps}

In the study, AHP, TOPSIS, and VIKOR methods were performed for determining suitable route for road planning. As a result of the study, $42 \%$ of the study areas had very high suitability for highway construction 
according to the TOPSIS and VIKOR calculations. Considering the weights of all criteria, elevation $22 \%$, land use $23 \%$ and slope have $9 \%$ importance in total weight calculation. Approximately $54 \%$ of the suitability composed of these criteria. Generated suitability maps (also cost surfaces) indicate that there is a good similarity and correlation between the AHP, TOPSIS, and VIKOR methods (Figure 4 and Table 4).

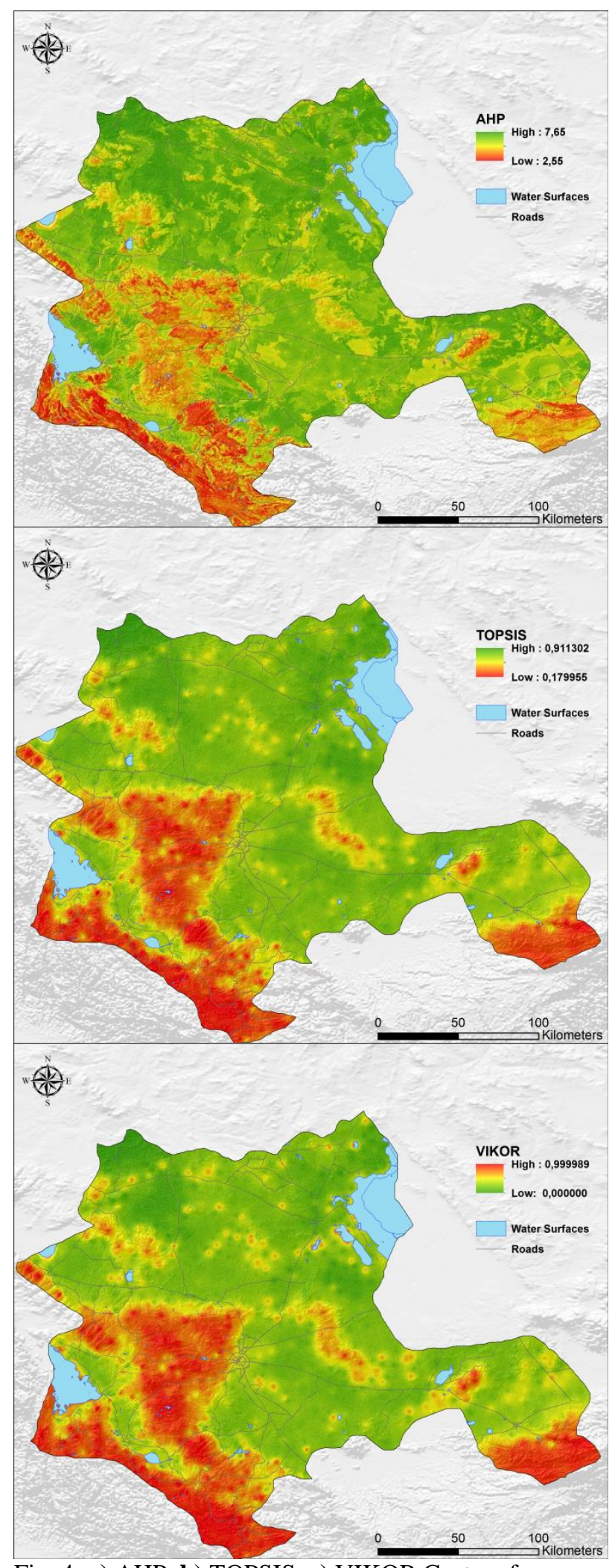

Fig. 4. a) AHP, b) TOPSIS, c) VIKOR Cost surfaces
According to the suitability results (Table 4), TOPSIS and VIKOR suitability rates are quite close to each other with $42,02 \%$ and $41,96 \%$. Although AHP suitability rate is less than others, sum of the high and moderate suitability rates are very close with $78,35 \%, 64,54 \%$, and $67,51 \%$ respectively. Thus, the AHP method calculated highest suitability rates.

Table 4. Suitability rates and statistics values

\begin{tabular}{|c|c|c|c|c|c|c|c|}
\hline & $\begin{array}{l}\text { M } \\
\text { in }\end{array}$ & $\begin{array}{l}\text { M } \\
\mathbf{a x}\end{array}$ & $\begin{array}{l}\text { Me } \\
\text { an }\end{array}$ & $\begin{array}{l}\text { High } \\
\text { Suita } \\
\text { bility }\end{array}$ & $\begin{array}{l}\text { Mode } \\
\text { rate } \\
\text { Suita } \\
\text { bility }\end{array}$ & $\begin{array}{l}\text { Low } \\
\text { Suita } \\
\text { bility }\end{array}$ & $\begin{array}{l}\text { Very } \\
\text { Low } \\
\text { Suita } \\
\text { bility }\end{array}$ \\
\hline AHP & $\begin{array}{l}1, \\
97\end{array}$ & $\begin{array}{l}7, \\
65\end{array}$ & $\begin{array}{c}5,7 \\
8\end{array}$ & $3,39 \%$ & $\begin{array}{c}74,96 \\
\%\end{array}$ & $\begin{array}{c}21,61 \\
\%\end{array}$ & $0,04 \%$ \\
\hline TOP & 0 , & 0 & 0,6 & 42,02 & 22,52 & 11,40 & 24,06 \\
\hline SIS & 18 & 91 & 1 & $\%$ & $\%$ & $\%$ & $\%$ \\
\hline VIK & 0 & 0 & 0,4 & 41,96 & 25,55 & 13,95 & 18,53 \\
\hline OR & 00 & 99 & 2 & $\%$ & $\%$ & $\%$ & $\%$ \\
\hline
\end{tabular}

\section{Generating LCPA Routes}

After generation of suitability maps, the least cost paths were determined for AHP, TOPSIS and VIKOR cost surfaces separately (Figure 5). The origin and destination points were defined considering the existing highways and intersections of highways connecting the districts. The region between origin and destination includes agriculture, forest, high mountains and related slope values, water resources, and both suitable and unsuitable geologic formations. Thus, the mentioned land characteristic features represent a good test surface for the generated routes and their reliability and applicability. LCPA routes are given in Figure 5.

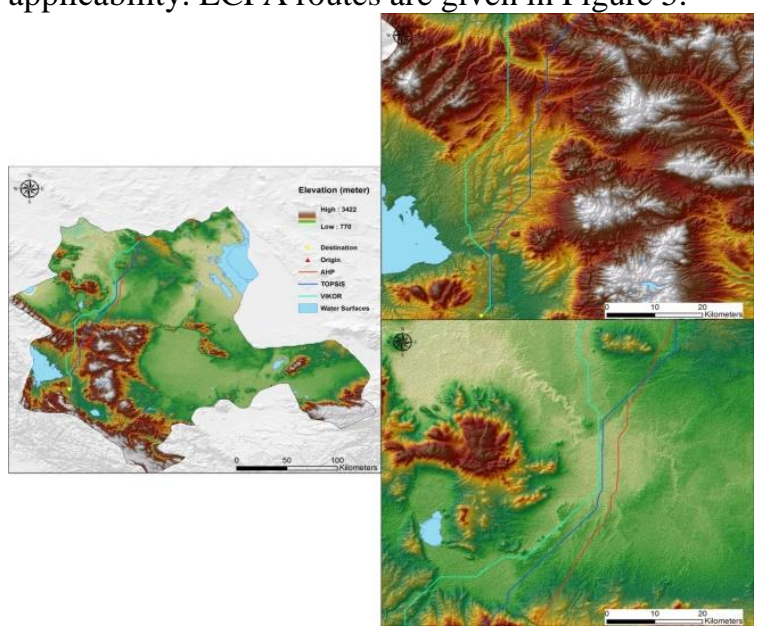

Fig. 5. Generated AHP, TOPSIS, and VIKOR routes

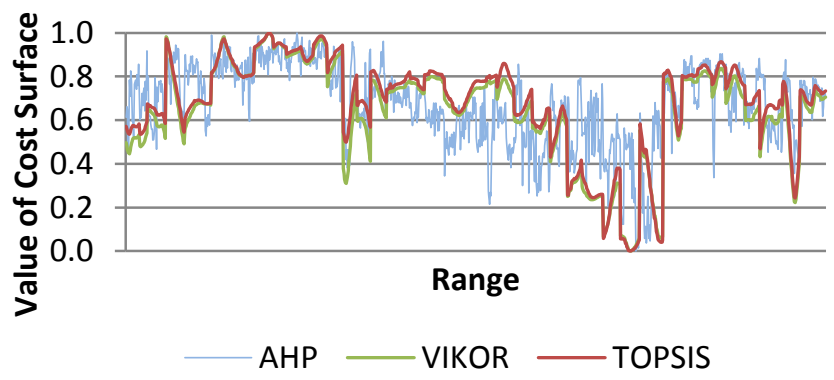

Fig. 6. AHP, VIKOR, and TOPSIS value of cost surface on current road 
Comparing the Generated Routes and Current Roads Current roads and AHP, VIKOR, and TOPSIS cost surfaces were compared with overlay analysis. Current roads were located on the cost surface on each method and the values of the each surface on current roads were extracted. The extracted values of these methods presented in Figure 6. According to the Figure 6, VIKOR and TOPSIS have almost similar trends. There are more fluctuations on AHP results. The locations of low values and high values are in the same regions for all methods. Moreover the average values of the cost surfaces are AHP 0.68, VIKOR 0.65, and TOPSIS 0.68. These results show that all the three methods consistent with each other and current road.

\section{Assessments on Topographical Surfaces}

$3 \mathrm{~d}$ view of the routes can give some idea about the routes behavior and priorities, before examining the detailed results. Therefore, the generated routes were overlapped with the DEM surface of the study area to understand the routes location and their characteristic features (Figure 7).
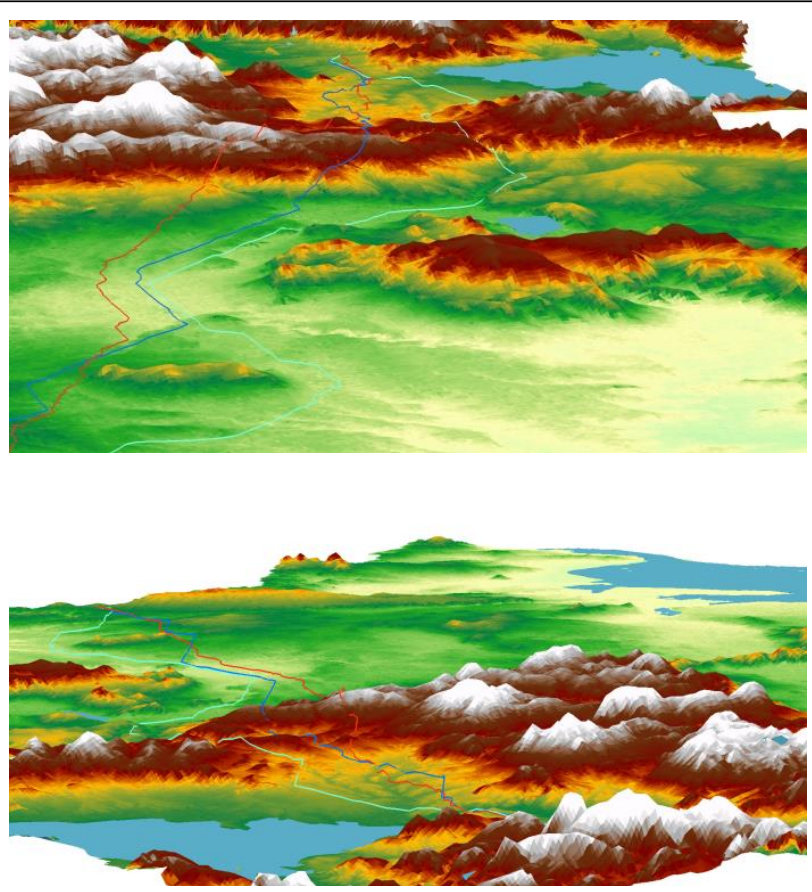

Fig. 7. 3D view of the AHP, TOPSIS and VIKOR routes

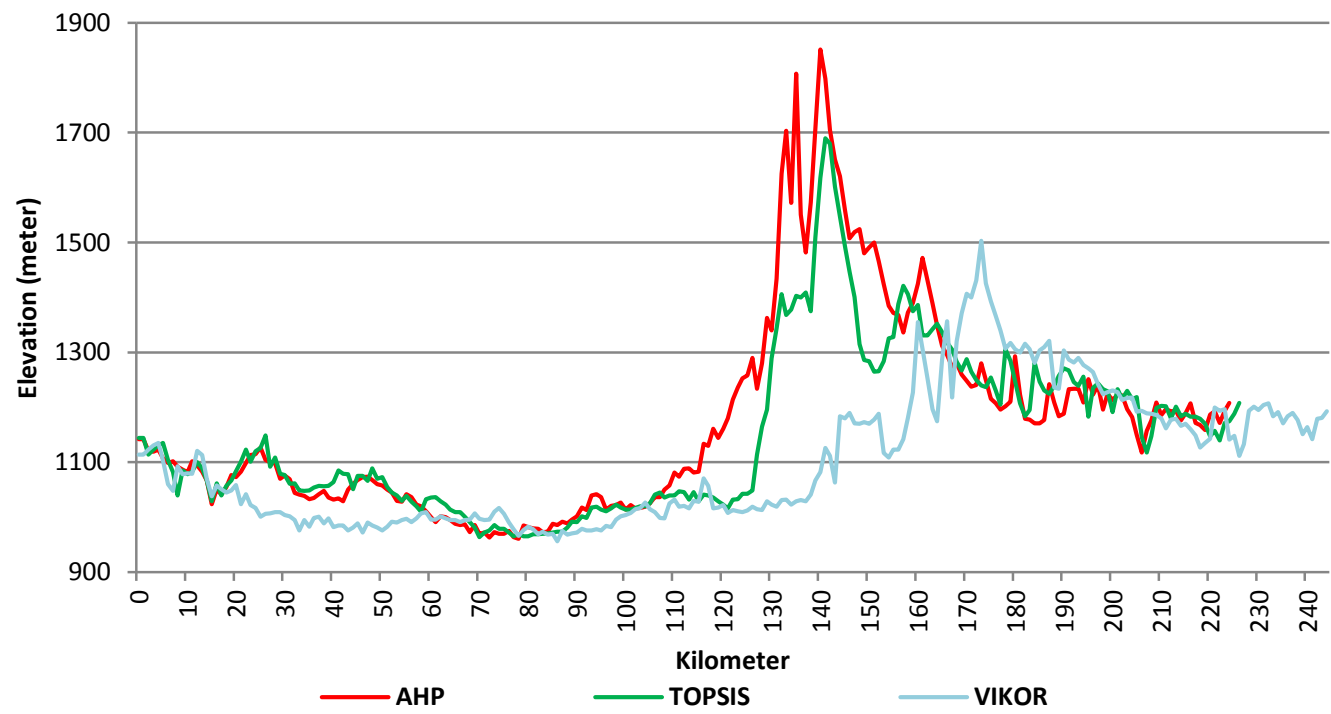

Fig. 8. Elevation comparison of generated routes.

Deciding the most suitable routes requires a comparison of the routes according to the elevation values. The routes tend to be close each other considering the homogeneous geographical distributions of the criteria. The comparisons of the routes are given below. First of all, elevations of the routes are the main decisive parameter of the costs. Comparison of the route profiles are given in Figure 8. AHP and TOPSIS routes tend to be located in higher elevation as it is seen in Figure 8. Thus, the excavation costs of the AHP and TOPSIS routes were increased. VIKOR route tends to be slighter than the others and it has less excavation costs.

In Figure 9, VIKOR route follows the contour lines better than other routes. Slope and elevation criterion have an increasing effect on construction costs. Beside the excavation cost, higher slope values require additional constructions such as retaining walls, splays, and culverts. Additionally, the average elevation of the routes is important in the field of climate conditions, temperature, and precipitation. The lengths of routes slope and elevation statistics of the routes are given in Table 5.

Table 5. Elevation and slope statistics of routes

\begin{tabular}{|c|c|c|c|c|c|c|c|c|c|}
\hline & \multicolumn{3}{|c|}{ AHP } & \multicolumn{3}{|c|}{ TOPSIS } & \multicolumn{3}{|c|}{ VIKOR } \\
\hline \multirow[t]{2}{*}{$\begin{array}{l}\text { Len } \\
\text { gths }\end{array}$} & \multicolumn{3}{|c|}{$228,30 \mathrm{~km}$} & \multicolumn{3}{|c|}{$224,89 \mathrm{~km}$} & \multicolumn{3}{|c|}{$244,71 \mathrm{~km}$} \\
\hline & $\begin{array}{c}\mathbf{M i} \\
\mathbf{n}\end{array}$ & $\begin{array}{c}\text { Ma } \\
\text { x }\end{array}$ & $\begin{array}{l}\mathbf{M} \\
\text { ea } \\
\mathbf{n} \\
\end{array}$ & $\begin{array}{c}\mathbf{M i} \\
\mathbf{n}\end{array}$ & $\underset{\mathbf{x}}{\mathbf{M a}}$ & $\begin{array}{l}\text { M } \\
\text { ea } \\
\mathbf{n}\end{array}$ & $\begin{array}{l}\mathbf{M} \\
\text { in }\end{array}$ & $\underset{\mathbf{x}}{\mathbf{M a}}$ & $\begin{array}{c}\text { M } \\
\text { ea } \\
\mathbf{n}\end{array}$ \\
\hline $\begin{array}{c}\text { Elev } \\
\text { atio } \\
\text { n }\end{array}$ & $\begin{array}{c}96 \\
1\end{array}$ & $\begin{array}{c}185 \\
1\end{array}$ & $\begin{array}{l}11 \\
71\end{array}$ & $\begin{array}{c}96 \\
4\end{array}$ & $\begin{array}{c}169 \\
0\end{array}$ & $\begin{array}{l}11 \\
47\end{array}$ & $\begin{array}{l}9 \\
5 \\
6\end{array}$ & $\begin{array}{c}150 \\
3\end{array}$ & $\begin{array}{l}11 \\
03\end{array}$ \\
\hline $\begin{array}{c}\text { Slop } \\
\text { e }\end{array}$ & $\begin{array}{l}0,3 \\
6 \%\end{array}$ & $\begin{array}{l}24 \\
74 \\
\%\end{array}$ & $\begin{array}{l}5,6 \\
9 \%\end{array}$ & $\begin{array}{l}0,3 \\
7 \%\end{array}$ & $\begin{array}{c}20, \\
24 \\
\%\end{array}$ & $\begin{array}{l}5,4 \\
5 \%\end{array}$ & $\begin{array}{l}0 \\
\%\end{array}$ & $\begin{array}{c}26, \\
12 \\
\%\end{array}$ & $\begin{array}{l}5,6 \\
0 \%\end{array}$ \\
\hline
\end{tabular}


While AHP and TOPSIS routes were located at higher elevation, VIKOR route was located at lower elevation than the others. The critical elevation of study region is 1500 meters above sea level which defines the start level of very hard winter conditions. When evaluating average slope values of routes, it seems that all routes had the same average slope (approximately 5,5\%) which can reduce the costs considerably. However, the lengths of the routes have also an important effect on costs and calculation of average slope value. The lengths were very close to each other, but TOPSIS route was shorter than the others generally. VIKOR route was the longest route because it tends to follow land surface and contour lines better than other routes.

Aspect criterion is related to meteorological conditions especially in winter seasons. The north faces of the roads tend to be icy and snowy considering the other directions. Thus, the direction rates of the routes are calculated and given in Table 6. VIKOR and AHP route has an advantage according to the aspect because they have low rate in North slopes and high rate in South slopes.

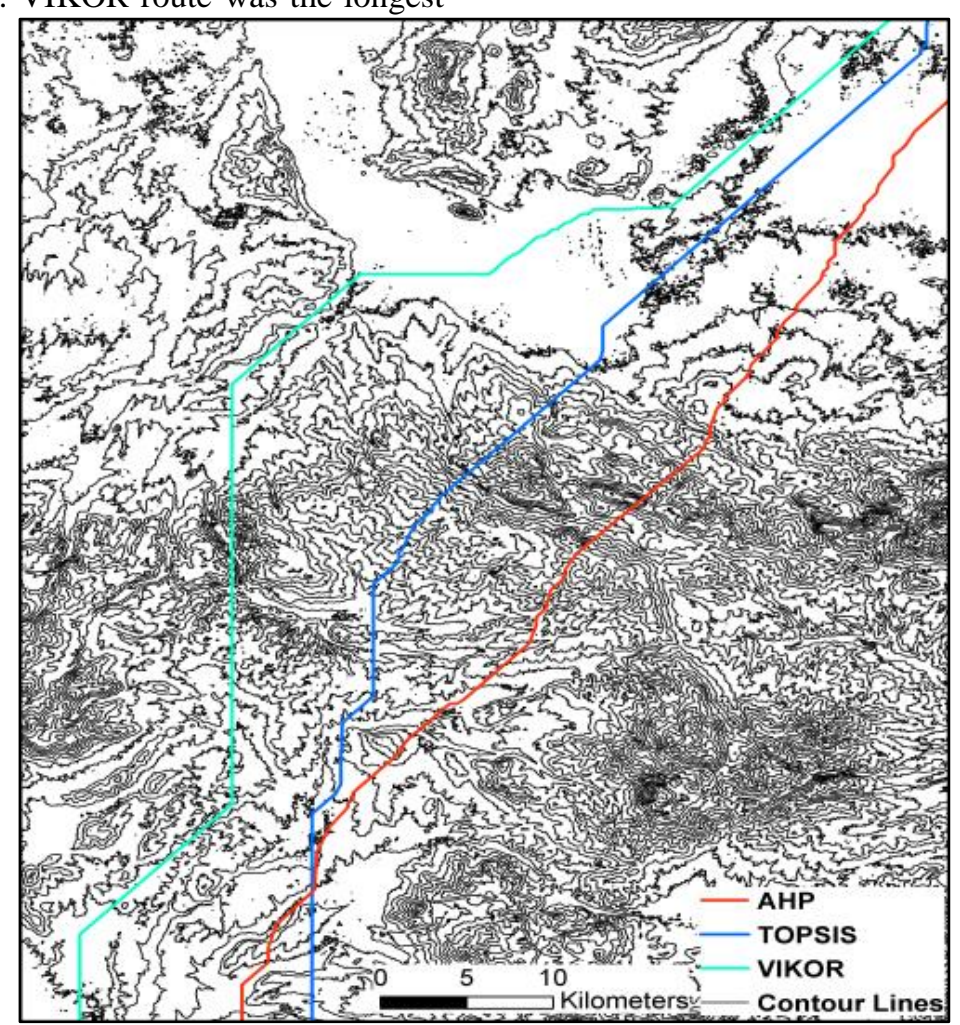

Fig. 9. Contour lines and routes.

Table 6. Aspect rates of the routes

\begin{tabular}{ccccc}
\hline & North & South & East & West \\
\hline AHP & $8,9 \%$ & $20,5 \%$ & $7,6 \%$ & $7,6 \%$ \\
TOPSIS & $14,2 \%$ & $15,0 \%$ & $8,4 \%$ & $11,5 \%$ \\
VIKOR & $11,9 \%$ & $21,3 \%$ & $12,3 \%$ & $11,1 \%$ \\
\hline
\end{tabular}

The routes were overlapped with land use and their statistical results are given in Table 7.

Table 7. Land use overlay of the routes

\begin{tabular}{cccc}
\hline & AHP & TOPSIS & VIKOR \\
\hline Mountain & $2,71 \%$ & $8,40 \%$ & $8,20 \%$ \\
Forest & $2,23 \%$ & $0,44 \%$ & $3,28 \%$ \\
Bare Lands & $0,00 \%$ & $0,00 \%$ & $1,63 \%$ \\
Agriculture & $95,06 \%$ & $91,16 \%$ & $86,89 \%$ \\
\hline
\end{tabular}

According to the Table 7, the AHP and TOPSIS routes are overlapped with agricultural lands mostly while the VIKOR route is overlapped with the mountains. However, VIKOR route is overlapped with agricultural lands mostly, and it tends to be overlapped with bare lands if exist.

\section{Conclusion}

GIS have emerged as powerful platforms for road planning. MCDA is an important component in GIS platform, and plays the key role in decision support. MCDA is increasingly important area in road planning. Because one of the greatest challenges in road planning issue is considering the environmental, socio-economic, geologic, topologic, and etc. factors together. GIS based MCDA can important role in addressing this issue. This paper describes the design and implementation of GIS based MCDA methods for road design. Moreover, the specific objective of this study was to compare three GIS based method performance for road design.

In this context, the most important factors are the criteria selection and data preparation for the study area. First, decision-makers should decide whether the project will be environmental or cost-driven according to the priorities of highway constructions. Then the weights of the criteria can be easily modified with AHP according to the priorities. Although 14 criteria were used in this study, more criteria can be added to protect the habitat such as migration routes of birds, the endemic plants, 
endangered animal live area, grasslands and organic agricultural lands. Thus, the realistic highway routes can be determined with enlarging the scope of the land facilities. Another important issue in this scope is the data collection and data accuracy. The spatial resolutions of the Aster Gdem data are 30 meters, so spatial resolution of the elevation, slope, and aspect were 30 meters. Thus, the accuracy of the project was maximum 30 meters. While this value is enough to determine suitability areas, higher resolutions will be getting better results.

Considering the suitability values and cost surfaces, they were quite close to each other. Nevertheless, the generated routes had different characteristic features and represented the expectations in different locations. These differences can enrich the decision process to be able to involve all possibilities and limitations together. It is very important to emphasize that the weight calculation stage has a critical process due to the usage of weights in each MCDA method. Modifying or updating weights will change the cost surfaces and also routes. Thus, the weights should be calculated accurately. Moreover, the classification of the criteria and related preference values should be determined carefully. Especially, threshold values and critical limit values (such as $10 \%$ max limit of the maximum slope of highways) should be reflected to the classification of the criteria if exist.

The results show that VIKOR route was the most suitable route considering the slope, elevation, land use, and aspect statistics. However, VIKOR route was longer than other routes, some excavation costs are equal to several kilometer road construction costs. Thus, experts should consider the cost of the routes when deciding. On the other hand, the routes should be investigated and minor modifying can be processed on highway routes. Especially, VIKOR route wasa determined within less slope and elevation. Thus, the routes can be intersected with the water collect and flow lines of the mountains and hills. This will increase the cost due to the new construction requirement such as culverts and drainage structures. According to the settlements, the crossroads and intersection points can be easily decided by an investigation process on the determined highway routes. Consequently, this study uses a qualitative case study approach to assess multi criteria for road planning and it was observed that integration of MCDA, LCPA, and GIS functions provide an effective platform to determine the suitability. Therefore this study makes a major contribution to research on road planning by considering multi criteria. It is expected that this GIS-based MCDA approach on road planning implemented elsewhere in the world.

\section{References}

Abbott, I., Butler, F., Harrison, S. (2012). When flyways meet highways - The relative permeability of different motorway crossing sites to functionally diverse bat species. Landscape and Urban Planning, 106(4), 293-302.
Arentze, T. A., Timmermans, H. J. P. (2000). ALBATROSS: A Learning-based Transportation Oriented Simulation System. EIRASS, Eindhoven University of Technology, The Netherlands.

Atkinson, D.M., Deadman, P., Dudycha, D., Traynor, S. (2005). Multi-criteria evaluation and least cost path analysis for an arctic all-weather road. Appl. Geogr. 25, 287-307.

Barber, C., Cochrane, M., Souza, C.M., Laurance, W. (2014). Roads, deforestation, and the mitigating effect of protected areas in the Amazon. Biological Conservation, 177,203-209.

Batterman, S., Cook, R., Justin,T. (2015). Temporal variation of traffic on highways and the development of accurate temporal allocation factors for air pollution analyses. Atmospheric Environment, 107, 351-363.

Black, W. R., (2003). Transportation: A Geographical Analysis. The Guilford Press, New York.

Burak, S., Doğan, E., Gazioğlu, C. (2004). Impact of urbanization and tourism on coastal environment, Ocean Coast Manag., 47, 15-527, doi.10.1016/ j.ocecoaman.2004.07.007.

Castaneda, D.A., Teixeira, E.C., Schneider, I., Pereira, F.N., Oliveira, M.L., Taffarel, S.R., Sehn, J.L., Ramos, C.G., Silva, L.F. (2016). Potential utilization for the evaluation of particulate and gaseous pollutants at an urban site near a major highway. Science of The Total Environment, 543 part A, 161170.

Çepni, M. S., Arslan, O. (2017). A GIS Approach to Evaluate Infrastructure Variables Influencing the Occurrence of Traffic Accidents in Urban Roads, International Journal of Environment and Geoinformatics, 4(1), 17-24, doi.10.30897 /ijegeo.306488

Coffin, A.W. (2007). From roadkill to road ecology: A review of the ecological effects of roads. Journal of Transport Geography, 15 (5), 396-406.

Collischonn, W., Pilar, J.V. (2000). A directional dependent least-cost path algorithm for roads and canals. Int. J. Geogr. Inform. Sci. 14 (4), 397-406.

Datta, S. (2012). The impact of improved highways on Indian firms. Journal of Development Economics, 99 (1), 46-57.

Dijkstra, E.W. (1959). A note on two problems in connection with graphs. Numerische Mathematik 1, 269-271.

Douglas, D.H. (1994). Least cost path in GIS using an accumulated cost surface and slope lines. Cartographica 31 (3), 37-51

Freitas, S.R., Hawbaker,T.J., Metzger, J.P. (2010). Effects of roads, topography, and land use on forest cover dynamics in the Brazilian Atlantic Forest. Forest Ecology and Management, 259 (3), 410-417.

Funderburg, R., Nixon, H., Boarnet, M., Ferguson, G.,(2010). New highways and land use change: Results from a quasi-experimental research design. Transportation Research Part A: Policy and Practice, 44(2), 76-98.

Hassan, O., Effat, H. (2013). Designing and evaluation of three alternatives highway routes using the Analytical Hierarchy Process and the least -cost path 
analysis, application in Sinai Peninsula, Egypt. The Egyptian Journal of Remote Sensing and Space Sciences, 16, 141-151.

Ho W., Xu X., Dey P. K. (2010). Multi-criteria decision making approaches for supplier evaluation and selection: a literature review. European Journal of Operational Research. 202(1), 16-24.

Holderegger, R., Giulio, D. M. (2010). The genetic effects of roads: A review of empirical evidence. Basic and Applied Ecology, 11 (6), 522-531.

Hwang, C, L., Yoon, K. (1981). Multiple Attribute Decision Making-Methods and Applications, Springer-Verlag, Heidelberg.

Jung, S., Lee, C.M., Kwon, T.S. (2013). Effects of Forest Roads on Hemipteran Diversity in Mt. Gariwang, Korea Test of Intermediate Disturbance Hypothesis. Journal of Asia-Pacific Biodiversity, 6(2), 239-248.

Lee, J., Stucky, D. (1998). On applying viewshed analysis for determining least-cost paths on digital elevation models. Int. J. Geogr. Inform. Systems 12 (8), 891-905.

Lewis, J., Rachlow, J., Horne, J., Garton,E., Wakkinen, W., Hayden, J., Zager,P. (2011). Identifying habitat characteristics to predict highway crossing areas for black bears within a human-modified landscape. Landscape and Urban Planning, 101 (2), 99-107.

Malczewski, J., 1999. GIS and Multicriteria Decision Analysis. John Wiley \& Sons.

Mohammad1, M., Hosseinal1, F. (2019). Assessment and Comparison the Location of Six Universities in Tehran City Using GIS and Multi Criteria Decision Making Methods, International Journal of Environment and Geoinformatics, 6(1), 143-147, doi10.30897/ijegeo.551753

Morelli, F., Beim, M., Jerzak, L., Jones, D., Tryianowski, P. (2014). Can roads, railways and related structures have positive effects on birds? - A review. Transportation Research Part D: Transport and Environment, 30,21-31.

Nader, M, F. (2006). Computers and Communication Networks, Prentice Hall, ISBN-13: 978-0131389106.

Newman, M.E., McLaren, K.P., Wilson, B.S. (2014). Assessing deforestation and fragmentation in a tropical moist forest over 68 years; the impact of roads and legal protection in the Cockpit Country, Jamaica. Forest Ecology and Management, 315,138152.

Opricovic, S. (1998). Multi criteria Optimization of Civil Engineering Systems, Faculty of Civil Engineering, Belgrade.

Pattinson, W., Longley, I., Kingham, S. (2014). Using mobile monitoring to visualise diurnal variation of traffic pollutants across two near-highway neighbourhoods. Atmospheric Environment, 94,782792.

Patton, A., Perkins, J., Zamore, W., Levy, J., Brugge, D., Durant, J. (2014). Spatial and temporal differences in traffic-related air pollution in three urban neighborhoods near an interstate highway. Atmospheric Environment, 99,309-321.

Peters, L., Zelewski, S. (2007). TOPSIS als Technik zur Effieienzanalyse, Zeitschrift für Ausbildung und Hochschulkontakt, 1-9.
Rees, W.G. (2004). Least cost paths in mountainous terrain. Computers \& Geosciences, 30, 203-209.

Saaty, T. L. (1977). A scaling method for priorities in hierarchical structures. Journal of Mathematical Psychology, 15, 234-281.

Saaty, T. L. (1994). Fundamentals of Decision Making and Priority Theory with the Analytical Hierarchy Process, RWS Publ. Pittsburg, 69-84,

Saaty, T. L., (1980). The analytical hierarchy process. New York: Wiley.

Saaty, T.L., Vargas, L.G. (1991). Prediction, Projection and Forecasting. Kluwer Academic Publishers, Dordrecht, $251 \mathrm{pp}$.

Sakthivel, G., Ilangkumaran, M., Gaikwad, A. (2015). A hybrid multi-criteria decision modeling approach for the best biodiesel blend selection based on ANPTOPSIS analysis. Ain Shams Engineering Journal, 6, 239-256.

Saunders, S., Mislivets, M.R., Chen, J., Cleland, D. (2002). Effects of roads on landscape structure within nested ecological units of the Northern Great Lakes Region, USA. Biological Conservation, 103 (2), 209225.

Schweikert, A., Chinowsky, P., Espinet, X., Tarbert, M. (2014). Climate Change and Infrastructure Impacts: Comparing the Impact on Roads in ten Countries through 2100. Procedia Engineering, 78, 306-316.

Stefanakis, E., Kavouras, M. (1995). On the determination of the optimum path in space. In: Proceedings of the European Conference on Spatial Information Theory, COSIT 95, Lecture Notes in Computer Science. Springer, Berlin.

Tanga, K., Waters, N, M. (2005). The internet, GIS and public participation in transportation planning. Progress in Planning 64, 7-62.

Triantaphyllou, E. (2000). Multi-Criteria Decision Making Methods: A Comparative Study, Kluwer Academic Publishers, Netherlands, 139-140.

Turkish Statistical Institute" (2019). Official website, (http://www.tuik.gov.tr/Start.do), (Mar. 11, 2019).

Vaghela, B. N. , Parmar, M. G. , Solanki, H. A. , Kansara, B. B. , Prajapati, S. K., Kalubarme, M. H. (2018). Multi Criteria Decision Making (MCDM) Approach for Mangrove Health Assessment using Geo-informatics Technology, International Journal of Environment and Geoinformatics, 5(2), 114-131, doi.10.30897/ijegeo.412511.

Wang, Y, M., Elhag T, M, S. (2006). Fuzzy TOPSIS method based on alpha level sets with an application to bridge risk assessment. Expert Systems with Applications, 31(2), 309-319.

Wu, C. F., Lin, Y., Ching, L., Huang, T. (2014). Assessing highway's impacts on landscape patterns and ecosystem services: A case study in Puli Township, Taiwan. Landscape and Urban Planning, 128, 60-71.

Yazdi, M., Delavarrafiee, M., Arhami, M. (2015). Evaluating near highway air pollutant levels and estimating emission factors: Case study of Tehran, Iran. Science of The Total Environment, 538, 375384. 
Yu, P.L. (1973). A class of solutions for group decision problems. Management Science 19 (8), 936-946.

Zeleny, M. (1982). Multiple Criteria Decision Making. Mc-Graw-Hill, New York.

Zhang, H., Wang, Z., Zhang, Y., Ding, M., Li, L. (2015). Identification of traffic-related metals and the effects of different environments on their enrichment in roadside soils along the Qinghai-Tibet highway. Science of The Total Environment, (521-522), 160172. 